\title{
Studi Pengelolaan Energi Listrik Di Perusahaan Pengolahan Daging PT. SOEJASCH BALI
}

\author{
H N Pratama ${ }^{1}$, R S Hartati ${ }^{2}$, I N S Kumara ${ }^{3}$
}

\begin{abstract}
PT. Soejasch Bali is a meat processing company that stood since 1983. In this paper conducted an energy audit of electrical and deph interview based questionnaire USAID - ICED to determine the intensity of energy consumption in the building of non-production of IKE $87.412 \mathrm{kWh} / \mathrm{m}^{2}$ and knowing Specific Energy Consumption for the calculation of the overall because it is a production company amounted to $887.62 \mathrm{kWh} / \mathrm{Ton}$. Energy Saving Opportunities that can be applied in PT. Soejasch Bali namely by setting operating hours which resulted in a $5 \%$ saving of energy consumed.
\end{abstract}

Intisari - PT. Soejasch Bali adalah perusahaan pengolahan daging yang berdiri sejak 1983. Dalam paper ini dilakukan audit energi listrik dan deph interview berdasarkan kuesioner USAID ICED untuk mengetahui Intensitas Konsumsi Energi di bangunan non produksi sebesar IKE $87,412 \mathrm{kWh} / \mathrm{m}^{2}$ dan mengetahui Konsumsi Energi Spesifik untuk perhitungan secara keseluruhan karena berupa perusahaan produksi sebesar 887,62 kWh/Ton. Peluang Hemat Energi yang bisa diterapkan di PT. Soejasch Bali yaitu dengan pengaturan jam operasional yang menghasilkan $5 \%$ penghematan energi yang dikonsumsi.

Kata Kunci- Manajemen Energi, Audit Energi, Intensitas Konsumsi Energi, Konsumsi Energi Spesifik, dan Peluang Hemat Energi.

\section{PENDAHULUAN}

Situasi umum tentang kebutuhan energi nasional setiap tahunnya mengalami pertambahan rata - rata $8,4 \%$ sekitar 5,700 Mega Watt. Biaya investasi untuk membangun infrastruktur kelistrikan adalah 88,4 triliun per tahun, sementara kemampuan PLN hanya sekitar 60 triliun per tahun [1]. Begitu pentingnya energi listrik bagi masyarakat pada suatu Negara, membuat pemerintah Indonesia mengeluarkan beberapa keputusan untuk konservasi energi, yaitu pada tahun 1991 Presiden mengeluarkan keputusan No. 43/1991 tentang Konservasi Energi [2], pada tahun 2006 Presiden kembali mengeluarkan keputusan No.5/2006 tentang Kebijakan Energi Nasional [3], dan pada tahun 2008 Presiden mengeluarkan instruksi No. 2/2008 tentang Penghematan Energi dan Air [4].

Studi pengelolaan energi pernah dilakukan di berbagai tempat, contohnya Singh H pada tahun 2011 melakukan audit energi di UiTM Penang hasilnya potensi penghematan $10 \%$, temuannya adalah $25 \%$ dari konsumsi energi listriknya untuk pencahayaan dan $56 \%$ untuk sistem penyejuk udara [5].

\footnotetext{
${ }^{I}$ Mahasiswa Magister Teknik Elektro, Fakultas Teknik, Universitas UDAYANA e-mail: henopra@yahoo.com

${ }^{2,3}$ Dosen Magister Teknik Elektro, Jurusan Teknik Elektro dan Komputer Fakultas Teknik Universitas Udayana, Jln. Jalan Kampus Bukit Jimbaran 80361 INDONESIA (telp: 0361703315; fax: 0361-4321; e-mail: rshartati@gmail.com inskumara@vahoo.com)
}

I W Swi Putra melakukan studi terhadap konservasi energi pada Gedung Sewaka Dharma Kota Denpasar yang menerapkan konsep Green Building tetapi pada kenyataannya adanya penambahan AC pada masing-masing ruangan menambah konsumsi energi listrik [6].

I Weda Setyawan meneliti tentang manajemen energi di Rumah Sakit Surya Husadha Denpasar hasilnya diketahui belum terkelola dengan baik namun dalam hal penerapan teknologi dan sistem perawatan peralatan khususnya lampu dan AC dapat dijadikan best practice [7], dan yang terakhir I B Putra Setanu M yang melakukan pengelolaan energi listrik pada Gedung Fakultas Kedokteran Universitas Udayana Kampus Sudirman Denpasar menghasilkan program SOP pengaturan jadwal pemakaian $\mathrm{AC}$ lampu, PC dan peralatan lainnya [8].

Indonesia Clean Energy Development (ICED) adalah program bantuan teknis yang didanai oleh United States Agency International Development (USAID) disektor energi yang mulai dilaksanakan tahun 2011 dengan tujuan untuk mendukung pemerintah, sektor swasta dan masyarakat untuk menggunakan energi yang bersih [9].

Paper ini bertujuan untuk mengetahui secara mendalam pengelolaan energi listrik yang ada di PT. Soejasch Bali berdasarkan kuesioner dari USAID ICED. Hasil dari studi pengelolaan energi listrik ini diharapkan bisa bermanfaat baik untuk kajian ilmu pengetahuan dan memberikan feedback yang menguntungkan pada PT. Soejasch Bali. Selain itu, juga sebagai pedoman awal bagi peneliti lain yang juga ingin meneliti hal yang sama atau penelitian lain yang masih berkaitan dengan penelitian ini pada masyarakat di masa yang akan datang.

\section{MANAJEMEN ENERGI}

Manajemen energi adalah suatu aktivitas manajemen energi yang berdisiplin, terorganisasi dan terstruktur menuju penggunaan energi yang lebih efisien, tanpa mengurangi tingkat produksi, kualitas serta ketentuan keselamatan dan pencemaran lingkungan [10].

Beberapa maanfaat manajemen energi yaitu menghemat biaya bagi industri atau perusahaan tanpa harus menggunakan pendekatan struktur untuk mengelola energi, peningkatan sumber daya manusia dan pengetahuan tentang efisiensi peralatan, meningkatkan citra dan kreadibilitas perusahaan terhadap seluruh stakeholder dan pelanggan, dan manfaat yang terakhir yaitu untuk peningkatan efisiensi operasional dalam pemeliharaan.

Langkah pertama manajemen energi yaitu dengan cara audit energi yang merupakan teknik yang digunakan untuk menghitung besarnya konsumsi energi pada bangunan gedung dan mengenali cara-cara untuk penghematannya. Audit energi merupakan aktifitas pemeriksaan berkala untuk mengetahui 
ada tidaknya penyimpangan dalam suatu kegiatan penggunaan energi. Audit energi juga dapat berguna dalam menelusuri dimana dan berapa energi yang digunakan, mengidentifikasi kebocoran atau ketidak efisienan energi, menentukan langkah perbaikannya serta mengevaluasi tingkat kelayakannya, kemudian hasilnya dibandingkan dengan standar yang ada sebagai bahan pertimbangan untuk dicarikan solusi penghematan penggunaan energi jika tingkat penggunaan energinya melebihi standar baku yang ada.

\section{A. Intensitas Konsumsi Energi}

Intensitas Konsumi Energi (IKE), yakni pembagian antara konsumsi energi dengan satuan luas bangunan gedung. Untuk bangunan selain bangunan produksi bsia menggunakan IKE sebagai acuan standarisasi manajemen energi yang ada[11].

$$
\mathrm{IKE}=\frac{\mathrm{TKL}}{\mathrm{TL}}
$$

Dengan :

IKE

TKL

: Intensitas Konsumsi Energi $\left(\mathrm{kWh} / \mathrm{m}^{2} / \mathrm{th}\right)$

TL perencanaan, yaitu seluruh pemakaian energi tahunan yang dihitung untuk suatu gedung yang direncanakan [13].

\section{USAID - ICED}

Kuesioner United States for International Development (USAID), Indonesia Clean Energy Development (ICED) sebagai bahan dept interview untuk mengetahui manajemen energi eksisting dan membantu mengidentfikasi peluang dalam melaksanakan peningkatan efisiensi energi. Kuesioner ini ditujukan untuk diisi dilapangan oleh perwakilan manajemen perusahaan. Bilamana memungkinkan, kuesioner ini sebaiknya diisi sebagai bagian dari pelaksanaan observasi lapangan, dimana praktek - praktek perawatan gedung dan hubungan antar pegawai juga dapat diamati.

\section{METODE}

Penelitian ini menggunakan dua perhitungan konsumsi energi listrik di PT. Soejasch Bali, yang pertama dengan menghitung Intensitas Konsumsi Energi dan kedua menghitung Konsumsi Energi Spesifik. Kuesioner dari USAID ICED untuk mengetahui secara mendalam pengelolaan energi listrik yang ada di PT. Soejasch Bali.

Data dalam penelitian ini berupa data kuantitatif yang diperoleh langsung dari keadaan terkini PT. Soejasch Bali, berupa audit energi awal, sumber daya manusia, teknologi, instalasi kelistrikan, perawatan, building envelope, total konsumsi energi dan total produksi pada tahun 2014 dan saat penelitian pada bulan Januari sampai dengan bulan Juni tahun 2015, setelah data - data tersebut diolah degan menghitung IKE \& KES nya, maka selanjutnya melakukan identifikasi potensi penghematan energi, yang bertujuan untuk mengetahui pola penggunaan energi \& potensi penghematan energi listrik di PT. Soejasch Bali.

\section{ANALISIS DAN HASIL PEMBAHASAN}

PT. Soejasch Bali merupakan distributor makanan yang semakin berkembang sejak berdiri di tahun 1983. Luas area $6,150 \mathrm{~m}^{2}$, jumlah karyawan dan staff sebanyak 327 orang, jumlah coling Unit 53, dan 117 mesin produksi. kegiatan produksi tersebut aktif dari hari Senin sampai dengan hari Sabtu dari jam 06. 00 WITA sampai dengan 17.00 WITA.

Untuk memenuhi kebutuhan di bidang kelistrikan.PT. Soejasch Bali di supplay oleh 3 unit transformator PLN berkapasitas $200 \mathrm{kVA}$. Serta menggunakan 2 generator set yang berkapasitas $200 \mathrm{kVA}$ dan $400 \mathrm{kVA}$ untuk mengantisipasi terjadinya gangguan listrik dari PLN dan memastikan produksi berjalan sesuai rencana.

Bangunan PT. Soejasch Bali terdiri dari empat buah bangunan yaitu bangunan Office, bangunan Produksi (gedung Mamas dan gedung Nikmat), bangunan Engineering dan bangunan Operasional, bangunan Engineering memiliki dua lantai, bangunan yang lain hanya satu lantai. Setiap bangunan memiliki jumlah ruang yang berbeda. Bangunan Office terdiri dari 22 ruangan, bangunan produksi Mamas terdiri dari 16 ruangan, bangunan produksi Nikmat terdiri dari 31 ruangan, bangunan Engineering terdiri dari 7 ruangan dan bangunan Oprasional terdiri dari 17 ruangan. Komposisi luas bangunan 
dan nama - nama ruangan PT. Soejasch Bali dapat dilihat diTabel 1:

TABEL I

KOMPOSISI LUAS BANGUNAN PT. SOEJASCH BALI

\begin{tabular}{|c|l|r|r|}
\hline No & Area & Luas Total $\left(\mathbf{M}^{\mathbf{2}}\right)$ & Luas Bangunan $\left(\mathbf{M}^{\mathbf{2}}\right)$ \\
\hline 1 & Office & 800 & 302 \\
\hline 2 & Produksi & 4.100 & 2.365 \\
\hline 3 & Engineering & 500 & 66 \\
\hline 4 & Operasional & 750 & 364 \\
\hline \multicolumn{2}{|c|}{ Total } & 6.150 & 3.097 \\
\hline
\end{tabular}

Data history konsumsi energi listrik di PT. Soejasch Bali, selama tahun 2014 ditunjukkan pada gambar 1dibawah ini:

\section{Konsumsi Energi Listrik}

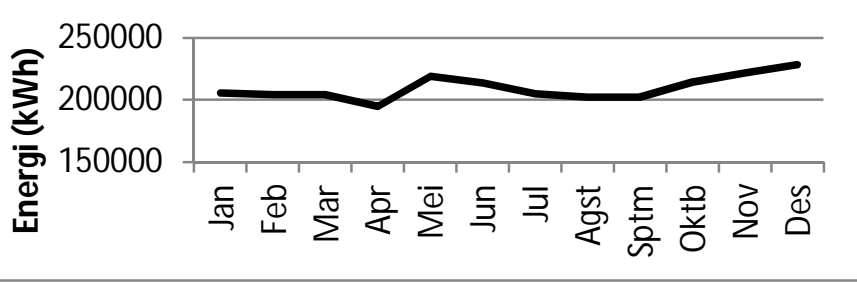

Gambar 1 Grafik Konsumsi Energi Listrik di PT. Soejasch Bali Tahun 2014

Merujuk pada gambar 1 diketahui konsumsi energi listrik PT. Soejasch Bali adalah 2.516.212 kWh dan juga jumlah total biaya yang harus dibayar untuk pengadaan energi listrik pada periode bulan Januari - Desember 2014 sebesar Rp $3,178,067,115$. Untuk total hasil produksi selama tahun 2014 yang sebesar 2.834.798 Ton mengacu pada gambar 2:

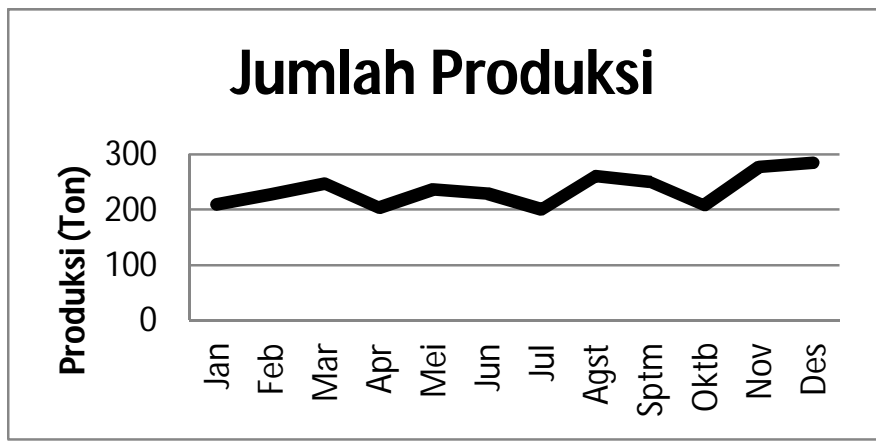

Gambar 2 Grafik Jumlah Produksi PT. Soejasch Bali Tahun 2014

\section{A. Manajemen Energi Eksisting di PT. Soejasch Bali}

Berdasarkan hasil depht interview menggunakan kuesioner USAID - ICED dengan nara sumber Asst Opr PT. Soejasch Bali untuk mengetahui pengelolaan energi eksisting di PT. Soejasch Bali diketahui bahwa sejak berdirinya PT. Soejasch Bali pada tahun 1983 belum pernah dilakukan audit energi. Dalam pelaksanaan Operations \& Maintenance $(\mathrm{O} \& \mathrm{M})$ di PT. Soejasch Bali pernah menggunakan jasa kontraktor luar yaitu PT. Panca Mitra Engineering untuk melaksanakan pekerjaan

H N Pratama: Studi Pengelolaan Energi Listrik...
Mechanical Electrical Plumbing (MEP) saat pembangunan gedung Nikmat tahun 2012. Untuk dokumentasi O\&M seperti spesifikasi teknis, gambar utilitas sistem sirkulasi udara, sistem pencahayaan dan sistem mekanik sudah ada di PT. Soejasch Bali.

Data biaya energi, penggunaan listrik, penggunaan gas, dan penggunaan minyak / bahan bakar lain, data - data tersebut dikumpulkan secara manual dan otomatis melalui sistem kontrol. Untuk semua ruangan data lampu, data mesin, data AC, data pompa, data komputer dan data konsumsi energi adalah data yang dikumpulkan saat penelitian ini berlangsung.

\section{Sumber Daya Manusia}

Direksi PT. Soejasch Bali berjumlah 3 Orang, setiap divisi memiliki manajer yang memimpin beberapa staf yang ada, diantaranya yaitu manajer Accounting, manajer Purchasing, manajer Operasional, dan manajer Security, jumlah staf dari berbagai divisi di PT. Soejasch Bali 57 Orang, untuk karyawan jumlahnya 230 Orang.

Dari jumlah total staf dan karyawan PT. Soejasch Bali kesadaran untuk menggunakan energi se efisien mungkin belum tertanam dalam mind set / alam bawah sadar mereka, karena meskipun ada sticker / poster tentang himbauan penghematan energi, contohnya 'matikan kran air jika sudah tidak diperlukan' dan 'matikan lampu jika pencahayaan alami sudah mencukupi' ternyata masih di jumpai kran air yang dibiarkan terbuka meskipun sudah diperlukan dan ada lampu tetap menyala di siang hari yang letaknya di area terbuka.

\section{Teknologi}

Sumber utama untuk pendingin gedung adalah AC split, untuk sumber utama ventilasi udara luar menggunakan Fresh Air dan Exhaust Fan. Untuk kipas angin, pompa, dan motor disetiap mesin produksi di PT. Soejasch Bali tidak menggunakan Variable Speed Drives. Sistem kontrol AC yang dimiliki PT. Soejasch Bali menggunakan Thermostat \& Remot untuk setiap AC yang ada, setiap thermostat di ruangan tidak dibatasi dalam hal kemampuannya untuk mengontrol suhu dalm ruangan. Untuk sistem kontrol pencahayaan masih manual. Semua kebutuhan AC dan pencahayaan tidak dikontrol secara otomatis, serta tidak ada set point temperature ruangan dinaikkan pada malam hari.

Jenis dan jumlah boilers yang digunakan untuk air panas di ruang produksi yaitu 5 unit Mauting Boil \& 2 unit New Auto Boil.Suhu air panas di ruang produksi diatur pada suhu 55' C60 'C, untuk pemeriksaan teratur terhadap kebocoran, kegagalan fungsi alat ukur, termperatur, saluran/pipa air dilakukan setiap 1 bulan sekali.Untuk pengaliran air ke storage tank dilakukan secara terus menerus.Tidak terdapat pengolahan air hujan dan air yang sudah digunakan untuk digunakan kembali.

Untuk menciptakan efek visual pada bangunan Office dan bangunan Nikmat di PT. Soejasch Bali menggunakan lampu spot light yang dinyalakan setelah jam kerja. Sebelum penelitian ini berlangsung belum pernah ada pengukuran tingkat pencahayaan. Saat melakukan ovservasi di PT. Soejasch Bali lampu - lampu yang ada belum ada yang p-ISSN:1693 - 2951; e-ISSN: 2503-2372

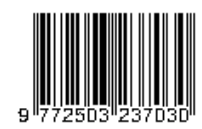


menggunakan lampu LED serta terdapat lampu - lampu yang digunakan secara konsisten tidak dimatikan meskipun disiang hari.

\section{Instalasi Kelistrikan}

Kondisi instalasi elektrikal di Sub Distribution Panel (SDP) Mamas tidak ada penandaan dan penamaan untuk memudahkan saat perawatan berkala, sedangkan di SDP Nikmat karena masih baru dibandingkan SDP Mamas instalasi elektrikalnya masih dilengkapi dengan penandaan dan penamaan.

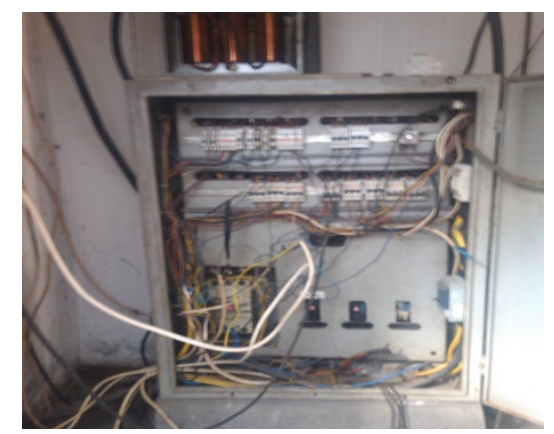

Gambar 3 Instalasi Panel Tanpa Marking \& Labelling

Kondisi kelistrikan PT. Soejasch Bali menunjukkan belum adanya teknologi kontrol dibandingkan dengan standar efisien Konsumsimsi Energi Spesifik (KES) yang menggunakan kontrol putaran dan Optimum Control Device [14], penambahan beban actual di SDP Mamas membuatnya kondisi panel tersebut tidak sesuai dengan gambar asbuilt drawing, serta masih adanya lampu di ruangan terbuka yang tetap menyala disiang hari yang membuat energi listrik yang ada di PT. Soejasch Bali terbuang percuma.

Kondisi kelistrikan dalam Ruang Produksi baik Nikmat maupun Mamas terinstal secara rapi dan aman, sama seperti di Ruang Kantor dan Ruang Operasional, untuk instalasi listrik di Ruang Genzet area depan kabel - kabel instalasi sudah tidak terinstal dalam conduit, serta penandaan dan penamaan di PKG sudah mulai hilang, hal ini menyulitkan para Mekanik saat proses perawatan dan perbaikan yang biasa terjadi jika adanya pemadaman lampu dari PLN.

\section{Maintenance}

Jumlah pegawai Operations \& Maintenance (O\&M) berjumlah 7 orang, dengan jadwal kerja yang dibagi menjadi 3 shift; pagi 3 orang, sore 2 orang dan malam 2 orang, untuk program inspeksi dan perawatan yang dilaksanakan secara teratur oleh tim O\&M frekuensi pelaksanaannya dilaksanakan 1 bulan sekali, pelatihan yang pernah diikuti oleh pegawai O\&M adalah pelatihan electrical \& pelatihan mechanical. Operational Manager adalah petugas yang bertanggung jawab mengelola konsumsi energi dan inisiatif lingkungan di PT. Soejasch Bali.

Filter AC dan Coil terakhir dibersihkan pada 20 april 2015, untuk jadwal pembersihan sendiri dilaksanakan rutin setiap bulannya. Jenis jendela di PT. Soejasch Bali adalah jendela kaca yang berkusen kayu.Dengan adanya air curtain dibeberapa ruangan menunjukkan adanya upaya menjaga keseimbangan tekanan udara positif / negatif.

\section{Building Envelope}

Atap bangunan berupa genteng metal yang memiliki daya serap terhadap sinar matahari yang tinggi, untuk jendela di Ruang Kantor menghadap ke arah utara, tidak ada jendela di Ruang Produksi Mamas \& Nikmat, jendela di Ruang Mekanik menghadap ke selatan dan jendela di Ruang Operasional menghadap ke utara, alat yang digunakan untuk mengukur temperature udara, pencahayaan dan kelembababan serta kebisingan suara di PT. Soejasch Bali menggunakan Environmental Meter merk PCE dengan Model EM882.

\section{B. Audit Energi Listrik}

Pada paper ini audit energi listrik di PT. Soejasch Bali yang pertama berdasarkan data konsumsi energi listrik selama tahun 2014 dan total hasil produksi selama tahun 2014, untuk Konsumsi Energi Spesifik (KES) PT. Soejasch Bali tahun 2014 bisa dilihat dari perhitungan 2 berikut:

$$
\begin{aligned}
\text { KES } & =\frac{\text { KEL }}{\mathrm{JP}} \\
& =\frac{2.516 .212}{2.834} \\
& =887.62 \mathrm{kWh} / \mathrm{ton}
\end{aligned}
$$

Dengan :

KES : Konsumsi Energi Spesifik (kWh/ton)

KEL : Konsumsi Energi Listrik (kWh)

JP : Jumlah Produksi yang dihasilkan (ton)

Yang kedua berdasarkan data peralatan yang mengkonsumsi energi listrik setiap harinya di PT. Soejasch Bali selama tahun 2015 seperti terlihat pada Tabel 2 dibawah ini dan total hasil produksi selama tahun 2014 karena saat proses penelitian ini di bulan Januari sampai dengan Juni 2015.

TABEL III

KONSUMSI ENERGI LISTRIK DI PT. SOEJASCH BALI

\begin{tabular}{|r|l|r|r|}
\hline No & \multicolumn{1}{|c|}{ Perangkat } & \multicolumn{1}{c|}{ Jumlah } & \multicolumn{1}{c|}{$\begin{array}{c}\text { Total } \\
\text { Konsumsi } \\
\text { (kWh/Hari) }\end{array}$} \\
\hline 1 & Lampu & 308 & 182 \\
\hline 2 & Peralatan Kantor & 100 & 211 \\
\hline 3 & Mesin Produksi & 117 & 5.717 \\
\hline 4 & Sirkulasi Udara & 48 & 508 \\
\hline 5 & Pompa & 8 & 264 \\
\hline \multicolumn{2}{|c|}{ Total } & & 6.884 \\
\hline
\end{tabular}


Konsumsi Energi Listrik

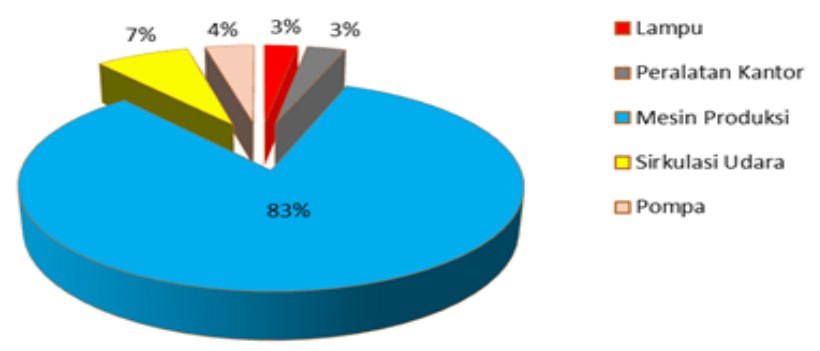

Gambar 5.Konsumsi Energi Listrik di PT. Soejasch Bali

Konsumsi Energi Spesifik (KES) PT. Soejasch Bali selama tahun 2015 bisa dilihat dari perhitungan berikut:

$$
\begin{aligned}
\mathrm{KES} & =\frac{\mathrm{KEL}}{\mathrm{JP}} \\
& =\frac{2.478 .250}{2.834} \\
& =874.23 \mathrm{kWh} / \mathrm{ton}
\end{aligned}
$$

Dengan :

$$
\begin{array}{ll}
\text { KES } & : \text { Konsumsi Energi Spesifik (kWh/ton) } \\
\text { KEL } & : \text { Konsumsi Energi Listrik (kWh) } \\
\text { JP } & : \text { Jumlah Produksi yang dihasilkan (ton) }
\end{array}
$$

Yang ketiga menghitung IKE di PT. Soejasch Bali

\begin{tabular}{|c|c|c|c|}
\hline No & Area & $\begin{array}{l}\text { Luas Total } \\
\left(\mathrm{M}^{2}\right) \\
\end{array}$ & $\begin{array}{c}\text { Konsumsi Energi } \\
(\mathrm{kWh} / \mathrm{bln})\end{array}$ \\
\hline 1 & Office & 800 & 10.141 \\
\hline 2 & Engineering & 500 & 2.388 \\
\hline 3 & Operasional & 750 & 2.404 \\
\hline \multicolumn{2}{|r|}{ Total } & 2.050 & 14.933 \\
\hline
\end{tabular}
berdasarkan gedung yang tidak terdapat mesin produksi dan tetapi tetap mengkonsumsi energi didalamnya seperti pada tabel 3 berikut:

TABEL IIIII

BANGUNAN NON PRODUKSI PT. SOEJASCH BALI

Intensitas Konsumsi Energi (IKE) PT. Soejasch Bali selama tahun 2015 bisa dilihat dari perhitungan berikut:

$$
\begin{aligned}
\mathrm{IKE} & =\frac{\mathrm{TKL}}{\mathrm{TL}} \\
& =\frac{179.196}{2.050} \\
& =87,412 \mathrm{kWh} / \mathrm{m}^{2}
\end{aligned}
$$

Dengan :

IKE $\quad$ : Intensitas Konsumsi Energi $\left(\mathrm{kWh} / \mathrm{m}^{2} / \mathrm{th}\right)$

TKL

: Energi listrik yang dikonsumsi (kWh/th)

Total Luas

: Luas Bangunan $\left(\mathrm{m}^{2}\right)$

\section{Rekomendasi Peluang Hemat Energi (PHE) di PT.} Soejasch Bali

Setelah dilakukan observasi pada setiap peralatan yang mengkonsumsi energi listrik di PT. Soejasch Bali diketahui 83\% H N Pratama: Studi Pengelolaan Energi Listrik... energi listrik di konsumsi oleh mesin produksi, sehingga rekomendasi PHE yang dipilih untuk diterapkan di PT. Soejasch Bali yaitu dengan pengaturan jam operasional / optimalisasi jam operasional mesin produksi yang semula 12 jam menjadi 10 jam tanpa mengurangi produktivitas yang ada, dimana PHE ini tidak membutuhkan biaya untuk menghasilkan efisiensi energi 5\% disetiap bulannya. Berikut gambar skematik PHE di PT. Soejasch Bali.

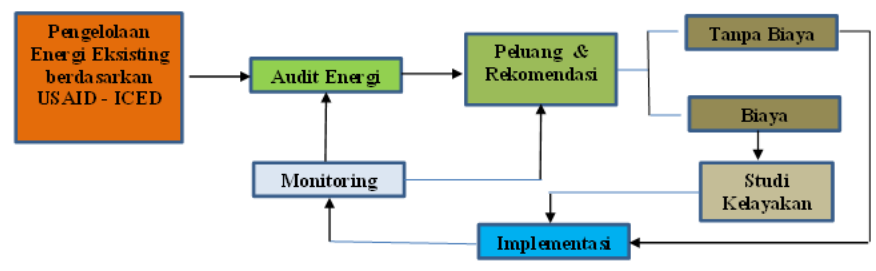

Gambar 6 Skema \& Siklus Pelaksanaan Program Penghematan Energi di PT. Soejasch Bali

Dari rekomendasi PHE tersebut, rekomendasi tanpa biaya yang di fokuskan untuk menurunkan konsumsi energi listrik hanya untuk operasional mesin produksi, yang pada akhirnya mampu menurunkan nilai IKE dan KES di PT. Soejasch Bali.

\section{Hasil Penghematan Energi dan Biaya Listrik di PT. Soejasch Bali}

Dari hasil anlisa penghematan yang diperoleh tanpa adanya investasi untuk implementasi PHE dengan cara optimalisasi jam operasional mesin produksi yang semula 12 jam menjadi 10 jam setiap harinya di PT. Soejasch Bali adalah sebagai berikut:

TABEL IVV

Hasil Perbandingan SEbelum dan SESUdah PHE

\begin{tabular}{|c|c|c|c|}
\hline No & Bangunan & $\begin{array}{c}\text { Total } \\
\text { kWh/hari } \\
\text { Sebelum } \\
\text { PHE }\end{array}$ & $\begin{array}{c}\text { Total } \\
\text { kWh/hari } \\
\text { Sesudah } \\
\text { PHE }\end{array}$ \\
\hline 1 & Nikmat1 & 2439.942 & 2122.943 \\
\hline 2 & Nikmat2 & 1607.826 & 1500.335 \\
\hline 3 & Mamas & 1669.638 & 1553.307 \\
\hline \multicolumn{2}{|c|}{ Total } & $\mathbf{5 7 1 7 . 4 0 6}$ & $\mathbf{5 1 7 6 . 5 8 5}$ \\
\hline
\end{tabular}

$$
\begin{aligned}
\mathrm{E} & =\mathrm{SBPHE}-\mathrm{SSPHE} \\
& =5.717,41-5.176,59 \\
& =540,83 \mathrm{kWh} / \mathrm{hari}
\end{aligned}
$$

Dengan :

E

$$
\begin{array}{ll}
\text { SBPHE } & : \text { Total }(\mathrm{kWh} / \text { hari) Sebelum PHE } \\
\text { SSPHE } & : \text { Total }(\mathrm{kWh} / \text { hari) Sesudah PHE }
\end{array}
$$

$P B E=B E x E$

$$
\begin{aligned}
& =\text { Rp. } 1 \cdot 086 \text { X 540,83 kWh/hari } \\
& =\text { Rp. } 587 \cdot 341,38
\end{aligned}
$$

Dengan :

PBE

BE

$\mathrm{E}$

\author{
: Penghematan Biaya Listrik (Rp/kWh/hari) \\ : Biaya Listrik (Rp) \\ : Energi Listrik (kWh)
}

p-ISSN:1693 - 2951; e-ISSN: 2503-2372 
Dari perhitungan diatas maka energi listrik yang bisa dihemat setelah mengimplementasikan PHE adalah 540,83 $\mathrm{kWh}$ per harinya, 46.224,9 kWh per bulannya, dan 554.698,8 $\mathrm{kWh}$ per tahunnya. Sedangkan biaya yang dihemat setelah mengimplementasikan PHE adalah Rp. 587.341,38 per harinya, Rp. 17.620.241,4 per bulannya dan Rp. 211.442.896,4 per tahunnya.

Konsumsi Energi Spesifik (KES) setelah implementasi PHE di PT. Soejasch Bali selama satu tahun bisa dilihat dari perhitungan berikut:

$$
\begin{aligned}
\mathrm{KES} & =\frac{\mathrm{KEL}}{\mathrm{JP}} \\
& =\frac{2.283 .555}{2.834} \\
& =805.55 \mathrm{kWh} / \mathrm{ton}
\end{aligned}
$$

Dengan :

$\begin{array}{ll}\text { KES } & \text { : Konsumsi Energi Spesifik (kWh/ton) } \\ \text { KEL } & \text { : Konsumsi Energi Listrik (kWh) } \\ \text { JP } & : \text { Jumlah Produksi yang dihasilkan (ton) }\end{array}$

\section{SIMPULAN}

Hasil studi pengelolaan energi listrik di perusahaan pengelolaan daging PT. Soejasch Bali mengelompokkan penggunaan energi berdasarkan konsumsi energi listrik berupa, lampu, peralatan kantor, mesin produksi, sirkulasi udara dan pompa. Untuk IKE PT. Soejasch Bali dihitung di bangunan non produksi yang menghasilkan IKE 87,412 $\mathrm{KWH} / \mathrm{M}^{2}$ sedangkan secara keseluruhan karena PT. Soejasch Bali merupakan perusahaan pengolahan daging maka KES nya $887,62 \mathrm{kWh} /$ Ton.

Rekomendasi penghematan energi yang bisa diterapkan di PT. Soejasch Bali untuk menurunkan konsumsi energi listrik adalah mengoptimalkan jam operasional mesin produksi, serta memastikan proses operasional PT. Soejasch Bali tidak terganggu dengan optimalisasi jam operasi mesin produksi yang semula 12 jam menjadi 10 jam untuk meningkatkan efisiensi energi listrik di PT. Soejasch Bali.

Setelah mengimplementasikan PHE di PT. Soejasch Bali energi listrik yang dapat dihemat sebesar 540,83 kWh per harinya. Sedangkan biaya yang dihemat setelah mengimplementasikan PHE adalah Rp. 587.341,38 per harinya. Untuk IKE PT. Soejasch Bali setelah Implementasi PHE yaitu 371,31 $\mathrm{kWh} / \mathrm{m} 2$ sedangkan untuk KES PT. Soejasch Bali $805.55 \mathrm{kWh} / \mathrm{ton}$.

\section{DAFTAR PUSTAKA}

[1] Mentri ESDM No 4092K/21/MEM/2013 tentang RUPTL PT PLN 2013-2022

[2] Presiden, Konservasi Energi,Keputusan Presiden No 43/1991

[3] Presiden, Kebijakan Energi Nasional, Peraturan Presiden No 5/2006

[4] Presiden, Penghemetan Energi dan Air, Instruksi Presiden No 2/2008

[5] Singh, H.; Seera, M.; Mohamad Idin, M.A., 2012 "Electrical energy audit in a Malaysian university - a case study,"Power and Energy (PECon), IEEE International Conference on , vol., no., pp.616,619, 2-5 Dec. 2012

[6] I W Swi Putra, IN Satya Kumara, IG Dyana Arjana, "Studi Terhadap Konservasi Energi Pada Gedung Sewaka Dharma Kota Denpasar Yang
Menerapkan Konsep Green Building” Jurnal Ilmiah Mahasiswa SPEKTRUM 2 (4), 7-13

[7] I Weda Setyawan, R Sari Hartatai, INS Kumara, "Manajemen Energi Di Rumah Sakit Surya Husadha”, Majalah Ilmiah Teknologi Elektro 11 (2)

[8] IB Putra Setanu M, R Sari Hartati, INS Kumara, "Pengelolaan Energi Listrik Pada Gedung Fakultas Kedokteran Universitas Kampus Sudirman Udayana", Majalah Ilmiah Teknologi Elektro 11 (2)

[9] (2015) The ICED website. [Online]. Available: http://www.iced.or.id

[10] (2011) Manajemen Energi. [Online]. Available: http://www.energyoffice.org/english/index.html.

[11] (2016) Dasar Energi. [Online]. Available: http://www.upliftindonesia.com/media/CEMseminar/3.Prinsip.pdf

[12] Anonim, “Global Industrial Energy Efficiency Benchmarking” Working Paper United Nation Industrial Development Organization tahun 2010

[13] Anonim, "Konservasi Eneergi Sistem Pencahayaan Pada Bangunan Gedung”. Badan Standarisasi Nasional 2011. SNI 036197-2000

[14] Badan Koordinasi Energi Nasional (1983). Buku Pedoman Tentang Cara-Cara Melaksanakan Konservasi Energi dan Pengawasannya. Jakarta: Departemen Pertambangan dan Energi. 